\title{
A CONSTRUÇÃO DO CONCEITO DE CONSCIÊNCIA EM Freud, MARX E AdORnO*
}

Camila Passos Fleury de Oliveira**

\section{RESUMO}

No presente artigo, o conceito de consciência será discutido a partir da leitura das obras de Freud, Marx e Adorno. Em alguns de seus textos, buscar-se-ão os elementos de análise, assim como o caminho percorrido por cada autor para o desenvolvimento e a apreensão de tal conceito. Ao final, será realizada uma análise a respeito das rupturas e aproximações dos três teóricos.

Palavras-chave: consciência; trabalho; civilização; indivíduo.

\section{A CONSTRUÇÃO DO CONCEITO DE CONSCIÊNCIA EM FREUd}

Freud, o fundador da psicanálise, estudou a fundo a psiquê humana. Dentre as suas incontáveis descobertas, o inconsciente aparece como o mais revelador e fundamental representante da teoria psicanalítica. Freud pôs a nu o fato de que o homem não é senhor de si como se comumente acreditava, mas, ao contrário, é guiado por pensamentos dos quais nem sempre tem conhecimento ou controle.

A tensão entre os sistemas consciente e inconsciente permeia toda a obra freudiana, e é dela que parte o desenvolvimento de suas principais contribuições. Em meio a essa tensão, uma certa confusão ou sobreposição de dois conceitos se faz presente. Embora pouco se reflita sobre esse tema nos escritos psicanalíticos, os termos "consciência" e "sistema consciente" aparecem como instâncias equivalentes, o que não

\footnotetext{
* Artigo recebido em 12/5/2005 e aprovado em 11/8/2005.

** Graduada em Psicologia (UCG) e mestranda em Educação Escolar Brasileira (FE-UFG). E-mail: cafleury@bol.com.br.
} 
é de fato correto, ainda que não se possa cindi-los por completo. É no interesse de identificar como se dá a construção do conceito de consciência em Freud que buscaremos, no interior de sua obra, os elementos que possibilitam sua análise.

Na teoria psicanalítica, a apreensão da gênese do conceito de consciência pode ser buscada na tensão existente na relação entre id, ego e superego, ou seja, no desenvolvimento do aparelho psíquico dos indivíduos. Como se dá o processo de desenvolvimento psíquico? Para Freud, este está diretamente vinculado ao funcionamento pulsional.

O corpo da criança, desde o momento do nascimento, é uma fonte de energia que, em contato com o mundo externo, buscará o objeto de que necessita para a satisfação do seu desejo. Essa energia da qual o corpo dispõe, denominada de libido, é canalizada para a obtenção do equilíbrio homeostático temporariamente perdido devido a alguma carência do organismo a qual Freud (1915) denominou de pulsão. ${ }^{1}$ Esta seria então "o representante psíquico dos estímulos somáticos". Para cada carência/ pulsão do organismo, existe um objeto correspondente, ou seja, o objeto da pulsão, que pode ser representado tanto por pessoas (mãe) quanto por coisas (alimento). A finalidade de cada pulsão seria obter satisfação que, em última análise, representa o retorno de um estado de equilíbrio.

No início da vida, o ambiente representa para a criança uma fonte de gratificações ou descargas para essas necessidades pulsionais que surgem do id e que motivam as relações do indivíduo com o mundo. Essa instância está sujeita às determinações daquilo que Freud (1911) denominou de princípio do prazer, segundo o qual o prazer deve ser alcançado de forma imediata sem considerar a realidade externa. Ao mesmo tempo em que o prazer é buscado, qualquer expressão de desprazer deve ser afastada. Como o objetivo do id é a obtenção imediata de prazer a qualquer preço, não é característica sua a preocupação com as restrições morais. Segundo Freud, "O id não conhece nenhum julgamento de valores: não conhece o bem nem o mal, nem moralidade" (1933, p. 79). As demandas dessa instância são imperiosas e imediatistas.

Como a figura materna é a maior fonte de gratificação pulsional que o indivíduo dispõe nesse momento, será altamente catexizada, ou seja, terá um grande investimento de energia psíquica. Nessa etapa, ainda não é possível falar de um ego diferenciado, já que a criança encontra-se em estado de fusão com a mãe. Devido a esse fator, segundo Freud, o seio da mãe é, nesse estágio, a mais desejada de todas as fontes e é 
também o primeiro objeto a contrastar a criança "sob a forma de algo que exige exteriormente e que só é forçado a surgir através de uma ação especial" (1930, p. 76), ou seja, por meio do choro. É a partir das primeiras experiências de frustração, quando a realidade externa é apresentada ao sujeito gradativamente, que este começará a desenvolver um sentido de realidade e a entender que existe um mundo externo independente dele próprio. A criança então aprende a diferenciar os estímulos provenientes do id daqueles oriundos do ambiente. Origina-se assim, a partir desse momento, um processo de diferenciação de um primitivo ego a partir do id.

O ego, nesse momento ainda primitivamente organizado, será o mediador entre os impulsos do id e o ambiente, a fim de encontrar meios de executá-los. Essa função de mediação é fundamental para o desenvolvimento do sujeito, como observa Freud:

a relação com o mundo externo tornou-se fator decisivo para o ego, esse assumiu a tarefa de representar o mundo externo perante o id que não poderia escapar à destruição se, em seus cegos intentos que visam à satisfação de seus instintos, não atentasse para esse poder externo supremo. (1933, p. 81)

Juntamente com esse processo de amadurecimento e diferenciação do ego, o sujeito progressivamente passa a adquirir a capacidade de adiar a descarga de energia até que as circunstâncias ambientais sejam favoráveis, ou seja, ele adquire a capacidade de tolerância. Desse modo, estão lançadas as bases para a introdução do princípio da realidade que, a partir desse momento, deve dominar o desenvolvimento futuro. Segundo Freud,

sob a influência dos instintos de autopreservação do ego, o princípio do prazer é substituído pelo principio da realidade. Este último princípio não abandona a intenção de fundamentalmente obter prazer; não obstante exige e efetua o adiamento da satisfação, o abandono de uma série de possibilidades de obtê-la e a tolerância temporária do desprazer como uma etapa no longo e indireto caminho para o prazer. (1920, p. 20)

Porém, o princípio do prazer nunca é abandonado e persiste nos sujeitos como uma tendência. Mas não são somente as pulsões relacionadas com a autopreservação que provém do id. Segundo Freud, as 
pulsões sexuais estão presentes desde o início da vida e não aparecem apenas como fruto do desenvolvimento posterior: "como todos sabem, as crianças de tenra idade são amorais e não possuem inibições internas contra seus impulsos que buscam o prazer" (1933, p. 67) Como não têm inibições, esse papel a princípio será desempenhado por seus pais. É função dos pais governar a criança, guiando suas atitudes, impondo leis e interdições e concedendo-lhe provas de amor, o que preparará o indivíduo para viver em sociedade. Com o conseqüente desenvolvimento da criança, essa influência externa, exercida pela autoridade dos pais, é internalizada sob a forma de um superego. De acordo com Freud, "Não devemos falar de consciência até que um superego se ache demonstravelmente presente" (1930, p. 139).

A influência dos pais governa a criança, concedendo-lhe provas de amor e ameaçando com castigos, os quais, para a criança, são sinais de perda do amor e se farão temer por essa mesma causa. Essa ansiedade realística é o precursor da ansiedade moral subseqüente. Na medida em que ela é dominante não há necessidade de falar em superego e consciência. Apenas posteriormente é que se desenvolve a situação secundária quando a coerção externa é internalizada, o superego assume o lugar da instância parental e observa, dirige e ameaça o ego, exatamente da mesma forma como anteriormente os pais faziam com a criança. (FreUd, 1933, p. 67-68)

O superego assume, assim, "o poder, a função e até mesmo os métodos da instância parental" (p. 68). Na origem do superego, as imagos parentais mais primitivas desempenham uma função determinante. É por meio da internalização do superego que a criança torna-se um ser moral e social.

Segundo Freud, "a base desse processo [de internalização da instancia parental] é o que se chama de identificação - isto é, a ação de assemelhar um ego a outro ego, em consequiência do que o primeiro ego se comporta como o segundo em determinados aspectos, imita-o, e em certo sentido, assimila-o dentro de si" (1921, p. 68). Dito de outro modo, "a identificação esforça-se por moldar o próprio ego de uma pessoa segundo o aspecto daquele que foi tomado como modelo" (1921, p.116).

A instalação do superego pode ser classificada como exemplo bemsucedido de identificação com a instância parental. $\mathrm{O}$ fato que fala 
decisivamente a favor desse ponto de vista é que essa nova criação de uma instância superior dentro do ego está intimamente ligada ao destino do Complexo de Édipo, de modo que o superego surge como herdeiro dessa vinculação afetiva tão importante para a infância. (FREUD, 1930, p. 69)

A identificação desempenha assim um papel decisivo na história primitiva do Complexo de Édipo: o menino tem em seu pai um ideal e, com base nessa admiração, gostaria de ser como ele. Concomitantemente a essa identificação com o pai, o menino começa a desenvolver um interesse especial pela mãe. O pai então assume o papel de rival, impedindo a concretização de seu desejo. A saída possível é renunciar a essas satisfações pulsionais:

a repressão que então se estabelece, compele-a [a criança] a renunciar a maior parte desses objetivos sexuais infantis e deixa atrás de si uma profunda modificação em sua relação com seus pais. A criança permanece ainda ligada a eles, mas por instintos que devem ser descritos como inibidos em seu objetivo. As emoções que daí passa a sentir por esses objetos de seu amor são caracterizadas como afetuosas. (FREUd, 1921, p. 121)

A resolução do Complexo de Édipo consiste em assumir sua identidade renunciando ao objeto de prazer. A criança, ao renunciar aos desejos edipianos amorosos e hostis, identifica-se com seus pais e internaliza suas interdições, assim como os valores dos pais e da sociedade. Essas identificações são fundamentais na formação do superego. A aquisição do sentimento de identidade forma-se a partir da elaboração das mais variadas identificações e sofrerá contínuas e sucessivas transformações ao longo da vida de cada indivíduo.

Abandonando o Complexo de Édipo, uma criança deve, conforme podemos ver, renunciar às intensa catexias objetais que depositou em seus pais, e é como compensação por essa perda de objetos que existe uma intensificação tão grande das identificações com seus pais, as quais provavelmente há muito estiveram presentes em seu ego. [...] No decurso do desenvolvimento, o superego também assimila as influências que tomaram o lugar dos pais, educadores, professores, pessoas escolhidas como modelos ideais. (FreUd, 1933, p. 69-70) 
Outro importante fator na formação do superego é, segundo Freud, a existência nos seres humanos de inclinação para a agressão: os homens "são criaturas entre cujos dotes instintivos deve se levar em conta uma poderosa quota de agressividade" (1930, p. 116). Freud afirma que provavelmente se tenha desenvolvido na criança uma agressividade contra a autoridade dos pais que a impede de ter algumas de suas primeiras satisfações pulsionais. Como essa agressividade vingativa que então se estabelece contra os pais não pode ser satisfeita, a criança é obrigada a renunciá-la e o faz por meio do processo de identificação e internalização da autoridade, processo esse que encontra-se, como ressaltamos, na origem do superego.

Quais os meios que a civilização utiliza para inibir a agressividade que se lhe opõe, torná-la inócua ou talvez livrar-se dela? [...] Sua agressividade [do indivíduo] é introjetada, internalizada: ela é na realidade enviada de volta para o lugar de onde proveio, isto é, dirigida no sentido do seu próprio ego. Aí é assumida por uma parte do ego que se coloca contra o resto do ego, como superego, e que então, sob a forma de 'consciência', está pronta para pôr em ação contra o ego a mesma agressividade rude que o ego teria gostado de satisfazer sobre outros indivíduos a ele estranhos. A tensão entre o severo superego e o ego, que a ele se acha sujeito, é por nós chamada de sentimento de culpa; expressa-se como uma necessidade de punição. A civilização, portanto, consegue dominar o perigoso desejo de agressão do indivíduo, enfraquecendo-o, desarmando-o e estabelecendo no seu interior um agente para cuidar dele, como uma guarnição numa cidade conquistada. (Freud, 1930, p. 127)

Freud nos esclarece que, na realidade, existem duas origens do sentimento de culpa: uma que surge do medo da autoridade e, posteriormente, outra que surge do medo do superego. No primeiro processo, o sentimento de culpa está diretamente vinculado ao medo da perda do amor: "o motivo que faz uma pessoa diferenciar o que é bom do que é mau é descoberto no desamparo e na dependência dela em relação a outros indivíduos, e pode ser mais bem designado como medo de perda do amor" (Freud, 1930, p. 128). O autor explica que de início aquilo que é considerado mau é o que de alguma forma ameaça a perda do amor e, conseqüentemente, da proteção a ele vinculada. $\mathrm{O}$ medo da perda do amor leva a uma renúncia das satisfações instintivas. O conflito entre a necessidade do amor e o impulso no sentido da satisfação instintiva geram 
o sentimento de culpa. Freud esclarece que nessa etapa o sentimento de culpa é apenas uma "ansiedade social" (1930, p. 129) Posteriormente, no segundo processo, a autoridade dos pais é internalizada por meio do estabelecimento do superego. Como nada pode ser escondido do superego, a distinção entre fazer algo mau e desejar fazê-lo desaparece completamente. De acordo com o autor, nesse momento "os fenômenos da consciência atingem então um estágio mais elevado. Na realidade então devemos falar de consciência ou sentimento de culpa" (129). Freud acrescenta que "o sentimento de culpa, a severidade do superego, é, portanto, o mesmo que a severidade da consciência" (1930, p. 139).

Segundo Freud (1930), podemos aprender que "a severidade do superego - as exigências da consciência" deve ser entendida como "uma continuação da severidade da autoridade externa, à qual sucedeu e que, em parte, substituiu" (p. 131).

De acordo com o autor (1930), pode-se afirmar que "a consciência é o resultado da renúncia instintiva, ou que a renúncia instintiva (imposta a nós de fora) cria a consciência, a qual então exige mais renúncias instintivas" (p. 131). Essa renúncia ao instinto, condição necessária para o estabelecimento de um superego (ou da consciência), desempenha um importante papel no desenvolvimento da civilização:

é impossível desprezar o ponto de vista o qual a civilização é construída sobre uma renúncia ao instinto, o quanto ela pressupõe exatamente a não satisfação (pela opressão, repressão, ou algum outro meio?) de instintos poderosos. Essa frustração cultural domina o grande campo das relações sociais entre os seres humanos. É a causa da hostilidade contra a qual todas civilizações têm de lutar. (FrEUD, 1930, p. 103-104)

No seu texto Mal-estar na civilização (1930), Freud estabelece uma relação direta entre os sacrifícios causados pela renúncia das satisfações pulsionais e a impossibilidade de o homem obter felicidade quando vivendo em sociedade. A consequiência dessa relação para a sociedade civilizada é que esta encontra-se em permanente ameaça de desintegração, o que a obriga a cuidar constantemente do estabelecimento e da manutenção dos limites reguladores das necessidades pulsionais dos homens. Segundo Freud,

Se a civilização impõe sacrifícios tão grandes, não apenas à sexualidade do homem, mas também à sua agressividade, podemos compreender 
melhor porque lhe é tão difícil ser feliz nessa civilização. [...] O homem civilizado trocou uma parcela de suas possibilidades de felicidade por uma parcela de segurança. (1930, p. 119)

É nesse processo - que se inicia com o nascimento do sujeito e se completa com seu desenvolvimento e que implica renúncias constantes - que Freud estabelece a construção do conceito de consciência ou de superego. No transcorrer de sua obra, podemos perceber que, para o autor, o superego e a consciência são instâncias equivalentes. Freud chega mesmo a afirmar que podemos denominar o superego como consciência "tranqüilamente".

A consciência não aparece em Freud como um conceito dado, mas como um processo em constante construção, na qual existe uma luta permanente entre desejo e renúncia, prazer e desprazer, satisfação e frustração.

\section{A CONSTRUÇÃo DO CONCEITO DE CONSCIÊNCIA EM MARX}

Segundo Marx, a existência humana constitui-se em determinadas condições históricas que demarcam as possibilidades de desenvolvimento de sua condição. Sendo assim, as possibilidades de o homem efetivar-se na realidade objetiva são determinadas pelo modo de produção material. Para compreender uma determinada sociedade, basta compreender sua estrutura produtiva.

Sendo assim, para compreender qual a perspectiva de Marx na análise do conceito de consciência, é preciso analisar seu modo de compreender a sociedade. Marx analisa a consciência a partir das condições de existência material, ou seja, através da análise das relações de produção.

Segundo a análise de Marx (2002), o ser humano, para além de sua condição biológica, se inaugura e se constitui como "ser" humano no registro de uma objetividade histórica, que só se efetiva pela mediação do trabalho. Assim, no centro do processo de constituição da humanidade, o trabalho aparece como dimensão fundamental. Nessa medida, a idéia de trabalho é vital para a compreensão do homem, de sua trajetória histórica e de sua realidade presente. O trabalho é, assim, a categoria explicativa do homem. 
Carente, o homem deverá por meio de sua ação produtiva criar as condições de possibilidade de sua existência, criando também, por essa via, o mundo em que vive. Nesse sentido, a necessidade é determinante na condução do homem ao trabalho, processo material de produção de sua vida. Está lançado, aí, o fato fundante da sociabilidade humana.

Segundo Marx e Engels (2002), o "primeiro pressuposto de toda a existência humana e, portanto, de toda a história" é "o de que todos os homens devem ter condições de viver para poder "fazer a história"" (p. 21).

Mas, para viver, é preciso antes de tudo beber, comer, morar, vestir-se e algumas outras coisas mais. O primeiro fato histórico é, portanto, a produção dos meios que permitem satisfazer essas necessidades, a produção da própria vida material; e isso mesmo constitui um fato histórico, uma condição fundamental de toda a história que se deve, ainda hoje como há milhares de anos, preencher dia a dia, hora a hora, simplesmente para manter os homens com vida. (MARX; ENGELS, 2002, p. 21)

Assim, o trabalho inscreve-se como a possibilidade de constituição e produção da humanidade. Através do trabalho, o homem constitui-se como homem e constitui a realidade material e espiritual em que vive. Nesse sentido, a relação entre sociedade e indivíduo apresenta-se como uma relação dialética de reciprocidade: produtor da realidade social, o homem também é, por ela, produzido.

Segundo Marx (1998), o processo de humanização concretiza-se por meio da relação de intercâmbio do homem com a natureza pela mediação do trabalho. Conforme as suas necessidades e no intuito de satisfazê-las, o homem atua sobre a natureza através da práxis humana, transformando-a e colocando-a a seu serviço.

Antes de tudo, o trabalho é um processo entre o homem e a Natureza, um processo em que o homem, por sua própria ação, media, regula e controla seu metabolismo com a Natureza [...]. Ao atuar, por meio desse movimento, sobre a natureza externa a ele e ao modificá-la, ele modifica, ao mesmo tempo, sua própria natureza. (MARX, 1998, p. 142)

É por meio de sua ação sobre a natureza, a partir de suas necessidades individuais, que o homem se exterioriza e se objetiva, 
refletindo-se assim no mundo objetivo. Assim, para Marx, a consciência aparece a princípio com a carência, o que determina a necessidade de intercâmbio com outros homens. Assim, como objetivação humana, o trabalho conserva, em si, a possibilidade da consciência.

A consciência é, portanto, de início, um produto social e o será enquanto existirem homens. Assim, a consciência é, antes de mais nada, apenas a consciência do meio sensível mais próximo e de uma interdependência limitada com outras pessoas e outras coisas situadas fora do indivíduo que toma consciência; é ao mesmo tempo a consciência da natureza que se ergue primeiro em face dos homens como uma força fundamentalmente estranha, onipotente e inatacável, em relação à qual os homens se comportam de um modo puramente animal e que se impõe a eles tanto quanto aos rebanhos; é, por conseguinte, uma consciência da natureza puramente animal (religião da natureza). (MARx; ENGELs, 2002, p. 25)

Ao criar os produtos de sua consciência que vão satisfazer suas necessidades, o homem deposita neles sua vida, subjetivando-os, ao mesmo tempo em que internaliza os objetos da realidade, internalizando dessa forma as consciências depositadas naquele objeto. Os conteúdos dos outros homens são, assim, internalizados como seus pelo processo de subjetivação e objetivação que constitui a realidade concreta. Nesse processo, as subjetividades encontram-se, constituindo, assim, a realidade social. Ao se exteriorizar em sua particularidade, o indivíduo é marcado pela universalidade.

Dessa forma, é no momento de confronto com suas necessidades que a consciência humana realiza-se. $\mathrm{O}$ ser da consciência constitui-se a partir - e ao mesmo tempo - do ser real concreto. A sua consciência será constituída nesse processo dinâmico de intercâmbio com as consciências dos outros indivíduos pela mediação do trabalho, no processo em que o sujeito, ao construir a realidade concreta, constrói-se a si mesmo. A consciência é assim produto de uma relação social, fruto do trabalho, que é um processo de socialização.

Mas o encontro do homem com a realidade em que vive é, no limite, o encontro com a vida humana passada, com as gerações que o precederam, das quais é herdeiro. Ao nascer, o homem herda uma realidade transformada por outros homens, marcada por suas consciências, e essa realidade condiciona as possibilidades de ação desse sujeito. Dessa 
forma, o homem atua sempre sob objetivações humanas pretéritas, já cristalizadas, significando-as e moldando-as conforme suas possibilidades presentes. Este é o segredo da história revelado por Marx e Engels:

A história não é senão a sucessão das diferentes gerações, cada uma das quais explora os materiais, os capitais, as forças produtivas que lhes são transmitidas pelas gerações precedentes; assim sendo, cada geração, por um lado, continua o modo de atividade que lhe é transmitido, mas em circunstâncias radicalmente transformadas, e, por outro lado, ela modifica as antigas circunstâncias entregando-se a uma atividade radicalmente diferente. (2002, p. 46-47)

Para Marx, então, a possibilidade da consciência não está dada no plano das idéias, mas, sim, no campo da sociabilidade, da realidade concreta.

Na produção social da própria existência, os homens entram em relações determinantes, necessárias, independentes de sua vontade; estas relações de produção correspondem a um grau determinado de desenvolvimento de suas forças produtivas materiais. O conjunto dessas relações de produção constitui a estrutura econômica da sociedade, a base real sobre a qual se eleva uma superestrutura jurídica e política e à qual correspondem formas sociais determinadas de consciência. $\mathrm{O}$ modo de produção da vida material condiciona o processo de vida social, política e intelectual. Não é a consciência dos homens que determina a realidade; ao contrario, é a realidade social que determina sua consciência. (MARX apud IANNI, 1995, p. 31-32)

Marx nos esclarece que esse mesmo trabalho que encerra a possibilidade de constituição do homem e de sua consciência pode converter-se no processo em que o homem pode se perder. Ao analisar a sociedade capitalista e sua forma de produção historicamente desenvolvida, Marx demonstra a complexidade do processo de alienação, revelando o aspecto negativo do trabalho e sua consequiência para a produção da consciência dos homens. Assim, para Marx, o trabalho manifesta-se em dois momentos contraditórios: como meio através do qual o homem constitui-se e como fator gerador de alienação e de constituição de uma falsa consciência. 
Com a consolidação do capitalismo como modo de produção material, ocorreram profundas transformações sociais e econômicas que modificaram drasticamente a existência humana. Economicamente, o trabalhador foi separado dos seus meios de produção, que se tornaram propriedade privada do capitalista, assim como do produto do seu trabalho. O trabalhador perdeu, dessa forma, o controle do processo global de produção e foi obrigado a vender a sua força de trabalho para viver. Uma nova forma particular de trabalho emergiu desse processo: o trabalho livre ou assalariado.

A idéia de trabalho livre é absolutamente necessária ao capitalismo. O trabalhador é livre para quê? Para vender sua força de trabalho, ou seja, para se vender como força de trabalho no mercado. É somente nessa forma desenvolvida historicamente que o trabalho assume as condições ideais de reprodução do capital. A força de trabalho convertese, dessa forma, em uma mercadoria, "a mais miserável de todas as mercadorias".

A força de trabalho é pois uma mercadoria que o seu proprietário, o operário assalariado, vende ao capital. E por que razão a vende? Para viver. Mas a manifestação da força de trabalho, o trabalho mesmo é a atividade vital própria do operário, a sua maneira específica de manifestar a vida. E é essa atividade vital que ele vende a um terceiro para conseguir os necessários meios de subsistência. Quer isto dizer que a sua atividade vital não é mais do que um meio para poder existir. Trabalha para viver. Para ele, o trabalho não é uma parte de sua vida, é antes um sacrifício da sua vida. É uma mercadoria que os outros utilizarão. (MARX, s.d., p. 22)

A existência do trabalhador fica assim condicionada à sua venda em uma relação de oferta e procura característica do mercado. Ao comprar a força de trabalho do homem, o capitalista não apenas adquiriu uma mercadoria, como também o direito de explorá-la:

o operário, cujo único recurso é a venda de sua força de trabalho, não pode desligar-se de toda a classe de compradores, isto é, da classe capitalista, sem renunciar à existência. Ele não pertence a este ou aquele patrão, mas à classe capitalista e compete-lhe a ele encontrar quem o queira, isto é, encontrar um comprador dentro dessa classe burguesa. (MARX, s.d., p. 23) 
A atividade produtiva do homem é agora canalizada para a produção de objetos que não lhe pertencem, pois são propriedade do capitalista. $\mathrm{O}$ trabalhador é assim alienado do produto de seu trabalho, do qual não apenas perdeu a posse como também não poderá usufruir como fruto de sua própria criação. Sem o controle do processo de produção, nem mesmo do produto final, o trabalhador não estabelece um vínculo com o produto de sua criação, e configura-se uma relação de oposição. O objeto produzido pelo trabalhador apresenta-se, assim, como um ser estranho e independente:

o objecto produzido pelo trabalho, o seu produto, se lhe opõe como um ser estranho, como um poder independente do produtor. $\mathrm{O}$ produto do trabalho é o trabalho que se fixou num objeto, que se transformou em coisa física, é a objectivação do trabalho. A realização do trabalho constitui simultaneamente a sua objectivação. A realização do trabalho aparece na esfera da economia política como desrealização do trabalhador, a objectivação como perda e servidão do objecto, a apropriação como alienação. (MARx, 1964, p. 159)

A consciência dos sujeitos exprime as relações sociais nas quais estão inseridos. Se, no sistema capitalista as relações sociais entre operário e capitalista são relações de dependência e alienação, é essa realidade que a consciência internalizará. As classes trabalhadoras apreendem essas relações de produção de maneira invertida, já que não surgem de forma transparente.

Marx, então, revela a existência de uma ligação entre formas invertidas de consciência e a existência material dos homens. O conceito de ideologia expressa, no limite, essa relação. Se a realidade não revela os nexos que a constituem e se apresenta de uma forma invertida, se as contradições sociais são ocultadas pela ideologia e, dessa forma, o sujeito é privado de tal entendimento, a consciência fica prejudicada pela distorção a que o pensamento é submetido. A consciência converte-se em uma consciência invertida, que é fruto de uma realidade invertida. Essa opacidade não é uma opacidade que está na consciência do sujeito, mas é uma opacidade que está na realidade.

O operário e o capitalista estão em um processo de compra e venda de força de trabalho e de produção de mercadoria, e é nesse processo que se funda a consciência de classe. E a consciência de cada 
um é determinada ou constituída pela posição que ocupa dentro do processo produtivo, de acordo com seus interesses que representam.

A perspectiva de classe não é a única, mas é a determinante na produção da consciência das pessoas e grupos sociais. O operário não pode elidir a alienação do produto do seu trabalho excedente (não pago), da mesma forma que o capitalista não pode elidir essa alienação. Sob as mais diversas formas, um luta para modificar essa situação, enquanto o outro luta para mantê-la. (IANNI, 1995, p. 26)

Segundo Marx e Engels (2002), as idéias da classe dominante tendem a ser as idéias predominantes em cada época. Essas idéias são generalizadas às demais classes de tal forma que acabam por transformarem-se em idéias naturais, perdendo seu caráter de historicidade.

Os pensamentos da classe dominante são também, em todas as épocas, os pensamentos dominantes; em outras palavras, a classe que é o poder material dominante numa determinada sociedade é também o poder espiritual dominante. A classe que dispõe dos meios de produção material, dispõe também dos meios de produção intelectual, de tal modo que o pensamento daqueles aos quais são negados os meios de produção intelectual está submetido também à classe dominante. Os pensamentos dominantes nada mais são do que a expressão ideal das relações materiais dominantes; eles são essas relações materiais dominantes consideradas sob forma de idéias, portanto a expressão das relações que fazem parte de uma classe, a classe dominante; em outras palavras, são as idéias de sua dominação. (2002, p. 48)

Mas, gradativamente, os operários passam a adquirir uma compreensão cada vez maior do caráter alienado de sua condição, no próprio interior de suas relações de trabalho. Uma consciência política começa a surgir paulatinamente, e os operários tendem a organizar as suas atividades a partir dessa compreensão. O operário começa a compreender o Estado burguês como o gerador da sua alienação. A sua consciência vai assim se desenvolvendo ao longo de suas próprias lutas, como classe.

Em seu Manifesto do Partido Comunista (1998), Marx defende o desenvolvimento de uma consciência política que possibilite elementos para uma revolução comunista, que rompa com as relações de produção 
tradicionais e promova uma melhoria nas condições de vida dos trabalhadores. Segundo o autor, a classe trabalhadora é "a classe revolucionária", ou seja, "é a classe que traz nas mãos o futuro" (MARX, 1988, p. 17). Marx levanta então uma questão:

Será necessária uma inteligência excepcional para compreender que, ao mudarem as condições de vida dos homens, as suas relações sociais, a sua existência social, mudam também as suas representações, as suas concepções, os seus conceitos - numa palavra, a sua consciência? (MARX, 1998, p. 28)

\section{A CONSTRUÇÃO DO CONCEITO DE CONSCIÊNCIA EM AdORNO}

Theodor W. Adorno foi um dos representantes que mais se destacou na chamada Escola de Frankfurt. Seus escritos incorporam uma preciosa crítica da sociedade, apoiada em uma interlocução com diversos teóricos, principalmente com Marx e Freud. Na teoria marxiana, Adorno busca os elementos objetivos que fundam a sociedade capitalista, que se sustenta nas contradições e nos conflitos. Na teoria freudiana, busca as causas subjetivas que tornam possível a adaptação e a adesão do sujeito a tal sociedade. Contudo, apesar de se valer de elementos da teoria marxiana e freudiana, Adorno não permite uma fusão ou sequer uma conciliação entre ambas. A tensão entre a objetividade e a subjetividade é inerente à sua obra. Seus escritos revelam, para além do tempo, a atualidade de sua análise.

A dialética entre indivíduo e sociedade é referência fundamental utilizada por Adorno na construção do conceito de indivíduo e na análise da cultura como um todo, servindo de parâmetro para a crítica da sociedade. No cerne do seu repertório analítico crítico, a razão iluminista aparece como elemento fundamental na gênese da irracionalidade produzida pelos homens. A razão iluminista, tomada como elemento de emancipação humana, possibilitada pelo progresso inerente à sua idéia, converte-se em seu oposto: instrumento de irracionalidade e regressão.

Dentro dessa perspectiva de crítica da sociedade, o conceito de consciência em Adorno aparece em dois pólos opostos: como meio de adesão ao mundo da cultura administrada e como seu contraponto, qual seja, a possibilidade de crítica e consequiente transformação da sociedade existente. É na transição entre esses dois pólos que se desenvolve a 
construção do conceito de consciência em Adorno, imanente à crítica do mundo da cultura administrada, crítica norteadora de sua obra.

No prefácio da obra Dialética do esclarecimento (1985), escrita por Adorno em conjunto com Horkheimer, uma questão aparece como crucial: "descobrir por que a humanidade em vez de entrar em um estado verdadeiramente humano está se afundando em uma nova espécie de barbárie" (p. 11). É apoiado nessa questão que os autores desenvolvem a sua crítica da sociedade.

Segundo Adorno, a sociedade capitalista converteu-se em uma sociedade inteiramente administrada pelos interesses do capital em detrimento dos interesses humanos. Permeado pela irracionalidade, o progresso converteu-se em progresso da dominação e transformou a consciência em sua presa fácil.

Nessa linha de raciocínio, segundo Crochik (2003), a dominação da consciência reflete-se na adaptação dos indivíduos a essa sociedade contraditória e irracional.

O que permite a adaptação a uma sociedade contraditória é a ideologia, que substitui, em grande parte, a força bruta direta necessária para que a ordem social se mantenha segundo os interesses dominantes, mas a ameaça da força é a substância. Assim, a consciência não reage diretamente ao conteúdo da ideologia, mas à ameaça. $\mathrm{O}$ que nos faz trabalhar continuamente é menos a justificativa ideológica e mais o medo do que aconteceria se assim não o fizéssemos. (CROCHIK, 2003, p. 21)

Segundo Adorno (1993), “a cultura cria a ilusão de uma sociedade digna do homem que não existe; ela escamoteia as condições materiais com base nas quais são produzidas todas as obras humanas [...] Tratase da noção da cultura como ideologia" (p. 48). Essa ideologia ceifa dos sujeitos a possibilidade de perceber a sua dominação, impedindo-o de se libertar dela. Estes converteram-se em obedientes instrumentos da ordem vigente, possibilitando a manutenção do existente por meio de uma adaptação passiva às leis da irracionalidade. A compreensão das condições de perpetuação da dominação, presente na sociedade atual, seja no indivíduo, seja na cultura, seria o primeiro passo para a sua eliminação, para uma transformação social. 
É importante frisar a falsidade inerente à ideologia atual que tem como um de seus principais traços fixar-se ao existente, dificultando a possibilidade de se pensar a transformação social necessária para uma sociedade justa. Se a ideologia atual tenta preservar o existente, a única alternativa que resta aos homens é a de se adaptar ou, em outras palavras, tornarem-se o que já são. Como não há possibilidade de transformação, só cabe aperfeiçoar o que existe. (СROCHÍK, 2003, p. 30)

No cerne da análise de Adorno, o que se percebe é uma denúncia: a impossibilidade de realização plena do indivíduo. A sociedade administrada retira do indivíduo a possibilidade de efetivar-se como sujeito emancipado, livre e autônomo, como um partícipe de uma sociedade verdadeiramente humana. O progresso, ao mesmo tempo que toma esses ideais como princípios, nega a sua possibilidade de realização. Esse é o paradoxo da razão iluminista:

hoje o homem adapta-se às condições dadas em nome do realismo. Os indivíduos sentem-se, desde o começo, peças de um jogo e ficam tranqüilos. Mas, como a ideologia já não garante coisa alguma, salvo que as coisas são o que são, até a sua inverdade específica se reduz ao pobre axioma de que não poderiam ser diferentes do que são. Os homens adaptam-se a essa mentira, mas, ao mesmo tempo, enxergam através do seu manto [...] a ideologia e a realidade correm uma para a outra; porque a realidade dada, a falta de outra ideologia mais convincente, converte-se em ideologia de si mesma, bastaria ao espírito um pequeno esforço para se livrar do manto dessa aparência onipotente, quase sem sacrifício algum. Mas esse esforço parece ser o mais custoso de todos. (Adorno; HorkHEIMER, 1973, p. 203)

A questão fundamental que permeia a obra de Adorno é: como é possível para a consciência a adesão a um ideário irracional? O que leva os indivíduos a aderir a essa cultura administrada?

Em seu texto "Acerca de la relación entre sociologia e psicologia" (1986), Adorno, ao buscar delimitar o objeto da psicologia social, aponta para a necessidade de se apreender os elementos que impossibilitam ao sujeito a percepção de sua condição de sujeitos dominados pela irracionalidade. No interior dessa discussão, a consciência aparece como objeto privilegiado de análise à medida que traz a chave do entendimento das 
razões subjetivas que levam o sujeito à adesão e à imobilização social. Segundo Crochík (2001),

A atual ideologia é mentira manifesta. [...] A crítica à ideologia, ou seja, à negação determinada, deve se voltar também aos mecanismos psíquicos que levam a adesão à mentira manifesta. Ou seja, a questão para esses autores é a de saber o que leva os homens a se conformar com uma sociedade que expropria continuamente os sentidos de suas vidas. (p. 6)

A indústria cultural, crítica fundamental de Adorno, reconstrói a sociedade opacizando-a, banindo a dialética da reflexão da consciência. Ao refletir a irracionalidade da sociedade capitalista, a indústria cultural, por meio da manipulação das massas, contribui para o surgimento de um sujeito identificado com a subjetividade que esta impõe. Assim, o que é externamente ditado pela indústria converte-se em necessidade interna, e o consumo revela mais uma forma de internalização da dominação. Dessa forma, desapropria do sujeito sua possibilidade de autodeterminação e contestação. O indivíduo busca se realizar de forma individualizada e fragmentada, perdendo a sua dimensão de universalidade. A heteronomia é a forma dominante do sujeito nessa sociedade. Segundo Adorno (1995),

a organização social em que vivemos continua sendo heterônoma, isto é, nenhuma pessoa pode existir na sociedade atual realmente conforme suas próprias determinações; enquanto isto ocorre, a sociedade forma as pessoas mediante inúmeros canais e instâncias mediadoras, de um modo tal que tudo absorvem e aceitam nos termos dessa configuração heterônoma que se desviou de si mesma em sua consciência. (p. 181)

Segundo Adorno (1972), "a formação não é outra coisa que a cultura pelo lado de sua apropriação subjetiva" (p. 142). Assim, é somente pelo processo de internalização da cultura que dar-se-á a diferenciação do sujeito com relação a seu meio. A cultura é o caminho possível para a individuação, que significa possibilidade de pensá-la, questioná-la. Ao internalizar a cultura administrada, o indivíduo internaliza a dominação. Nesse sentido, o processo de individuação é impedido pelo processo de individualização, incentivado pela indústria cultural e que retira dos sujeitos a capacidade de crítica. Segundo Adorno (1995), "atualmente a sociedade premia uma não individuação, uma atitude colaboracionista” (p. 153). 
$\mathrm{Na}$ indústria, o indivíduo é ilusório não apenas por causa da padronização do modo de produção. Ele só é tolerado na medida em que sua identidade incondicional com o universal está fora de questão. [...] o que domina é a pseudoindividualidade. [...] a individuação jamais chegou a se realizar de fato. O indivíduo, sobre o qual a sociedade se apoiava, trazia em si mesmo sua mácula; em sua aparente liberdade, ele era o produto de sua aparelhagem econômica e social. (ADORNO; HORKHEIMER, 1985, p. 144-145)

Segundo Crochík (2001), "como a formação, a diferenciação individual, significa a apropriação subjetiva da cultura, o que essa tem de racionalidade e de irracionalidade é transposto para o indivíduo" (p. 7). Nesse processo, o indivíduo é levado a aceitar as condições que a sociedade impõe passivamente, acatando, como seus, os padrões sociais impostos. O sujeito, ao se relacionar com a realidade, internaliza essa realidade em sua forma aparencial que oculta a sua forma de opressão, o que impossibilita a consciência dela, do seu processo de opressão. Assim, os sujeitos, destituídos de sua própria história, perpetuam sua condição alienada e alienante.

A possibilidade de constituir-se como sujeito está dada na possibilidade de ter consciência de si. A consciência manipulada é um reflexo de um sujeito que desconhece a si mesmo, ainda que acredite que tenha o controle de si. Ao reproduzir as formas de dominação, deixa de construir a sua possibilidade de mudança para perpetuar-se como sujeito da sujeição. A indústria cultural contribui maciçamente para o impedimento de que haja transformação social à medida que a idéia que se difunde é que esta já existe.

A indústria cultural é emblemática da perda da dimensão emancipatória que deveria ser imanente ao movimento da razão. Adorno (1995) defende o princípio do esclarecimento da consciência que inevitavelmente levaria a um questionamento e a uma resistência à sociedade em contraponto ao que chama de "conformismo onipresente" (p. 144). Para o autor, "de um certo modo, emancipação significa o mesmo que conscientização, racionalidade” (AdORNO, 1995, p. 143).

Uma idéia vendida pela indústria cultural e que perpassa a democracia é a de que os indivíduos desfrutam não somente da igualdade de direitos como, de fato, de possibilidades, dificultando a identificação dos mecanismos de dominação. Negando-se a desigualdade social historicamente determinada no modo de produção capitalista, difunde-se a 
crença na possibilidade de uma sociedade igualitária com oportunidades ao alcance de todos, na qual o esforço individual levaria conseqüentemente à mobilidade social. Esta é a idéia produzida pela racionalidade capitalista e absorvida pela consciência. Segundo Adorno (1995), "Uma democracia efetiva só pode ser imaginada enquanto uma sociedade de quem é emancipado" (p. 142).

Numa democracia, quem defende ideais contrários à emancipação, e, portanto, contrários à decisão consciente independente de cada pessoa em particular, é um antidemocrata, até mesmo se as idéias que correspondem a seus desígnios são difundidas no plano formal da democracia. As tendências de apresentação de ideais exteriores que não se originam a partir da própria consciência emancipada, ou melhor, que se legitimam frente a essa consciência, permanecem sendo coletivistas-reacionárias. Elas apontam para uma esfera a que deveríamos nos opor não só exteriormente pela política, mas também em outros planos muito mais profundos. (ADORNo, 1995, p. 142)

Em Adorno, a discussão do conceito de consciência é equivalente à discussão da racionalidade. Assim, não é possível pensá-la senão inserida dentro da crítica da sociedade, pois, para ele, a consciência não se restringe a um mero pensar, mas a um pensar que possa resultar conseqüentemente em ação. Para o autor o "conceito de racionalidade ou de consciência" é, em geral,

apreendido de um modo excessivamente estreito, como capacidade formal de pensar. Mas esta constitui uma limitação da inteligência, um caso especial da inteligência, de que certamente há necessidade. Mas aquilo que caracteriza propriamente a consciência é o pensar em relação à realidade, ao conteúdo - a relação entre as formas e estruturas de pensamento do sujeito e aquilo que este não é. Este sentido mais profundo de consciência ou faculdade de pensar é o mesmo que fazer experiências. Eu diria que pensar é o mesmo que fazer experiências intelectuais. Nesta medida, e nos termos que procuramos expor, a educação para a experiência é idêntica à educação para a emancipação. (ADORNo, 1995, p. 151)

Conforme o autor, como a sociedade em que vivemos é regida pela dominação e pela irracionalidade, a formação cultural "se converte em uma pseudoformação socializada, na onipresença do espírito alienado [...] a pseudoformação passou a ser a forma dominante da consciência 
atual" (ADORNo, 1972, p. 142). Sem liberdade não há autonomia e sem autonomia não há possibilidade de reflexão e crítica.

A análise de Adorno a respeito da consciência, nessa sociedade convertida em consciência manipulada, culmina com uma reflexão acerca da educação como único meio possível de negação e resistência. Adorno (1995), ao apresentar sua concepção de educação, defende não "a chamada modelagem de pessoas", nem tampouco "a mera transmissão de conhecimentos", "mas a produção de uma consciência verdadeira. Isso seria inclusive de maior importância política" (p.141). Alcançar esse objetivo em uma sociedade que subtrai do homem a possibilidade de tornar-se um sujeito autônomo, crítico do sistema em que vive, não é tarefa fácil. Como produzir consciências verdadeiras em uma sociedade que forma (e conforma) seus membros à realidade tal como está posta?

Tamanho empreendimento não constitui tarefa fácil. Para tanto, o resgate de uma Educação que priorize a formação de sujeitos autônomos faz-se vital. Este deve ser o primeiro passo para a construção de uma possível resistência à hegemônica racionalidade instrumental capitalista. Para Adorno (1995), somente através da construção desse processo crítico, tendo como objetivo a educação para a emancipação, seria possível impedir a barbárie. "[...] a única concretização efetiva da emancipação consiste em que aquelas poucas pessoas interessadas nesta direção orientem toda a sua energia para que a educação seja uma educação para a contradição e para a resistência" (p. 183).

A educação seria impotente e ideológica se ignorasse o objetivo de adaptação e não preparasse os homens para se orientarem no mundo. Porém ela seria igualmente questionável se ficasse só nisso, produzindo nada além do que Well ajusted people, pessoas bem ajustadas, em conseqüência do que a situação existente se impõe precisamente no que tem de pior. Nestes termos, desde o início, existe no conceito de educação para a consciência e para a racionalidade uma ambigüidade. Talvez não seja possível superá-la no existente, mas certamente não podemos nos desviar dela. (ADORNo, 1995, p. 143-144)

\section{CONSIDERAÇÕES FINAIS}

Após percorrer um longo período a fim de obter a apreensão do conceito de consciência na originalidade das obras de Freud, Marx e 
Adorno, é possível agora buscar os elementos que permitem identificar as aproximações e divergências entre os autores citados.

De acordo com Freud (1933), a origem do superego ou da consciência "pressupõe um fato biológico extremamente importante e um fato psicológico decisivo; ou seja, a prolongada dependência da criança em relação a seus pais e ao Complexo de Édipo, ambos intimamente relacionados" (p. 72). Assim, em sua obra, percebemos que o interesse de Freud está voltado para o modo como, na origem da consciência, se dá a interação entre os fatores biológicos e psíquicos, ou seja, como, a partir das apetências e necessidades físicas, o indivíduo se constrói como um ser psíquico.

Ao refletir sobre a origem do superego ou da consciência, Freud (1933) ressalta que "Quando levamos em conta o superego estamos dando um passo importante para a nossa compreensão do comportamento social da humanidade" (p. 72). Os fatores psicológicos são, na visão do autor, imprescindíveis para qualquer análise que se queira fazer sobre a civilização, já que esta é constituída por seres humanos e para seres humanos. Assim, em sua análise, considera os fatores psíquicos determinantes em qualquer fator relativo à cultura.

Ao analisar os textos de Marx e Freud, percebemos que ambos apresentam focos de análise distintos. Enquanto para Marx a objetividade sobrepõe-se à subjetividade, em Freud ocorre o oposto:

Parece provável que aquilo que se conhece como visão materialista da história peque por subestimar esse fator. Ele põe de lado, com o comentário de que as 'ideologias' do homem nada mais são do que produto e superestrutura de suas condições econômicas contemporâneas. Isto é verdade, mas muito provavelmente não a verdade inteira. A humanidade nunca vive inteiramente o presente. O passado, a tradição da raça e do povo, vive nas ideologias do superego e só lentamente cede às influências do presente, no sentido de mudanças novas; e enquanto opera através do superego, desempenha um poderoso papel na vida do homem, independente de condições econômicas. (FreUd, 1933, p. 73)

A consciência para Marx é determinada pelas relações sociais do indivíduo, relações de produção. Já, para Freud, a consciência dá-se a partir do desenvolvimento pulsional dos indivíduos por meio da luta entre os desejos pulsionais e a sua repressão. A análise de Marx é objeto de crítica de Freud: 
A força do marxismo está, evidentemente, não em sua visão da história, ou nas profecias do futuro baseadas nela, mas sim na arguta indicação da influência decisiva que as circunstâncias econômicas dos homens têm sobre as suas atitudes intelectuais, éticas e artísticas. Com isso foram descobertas numerosas correlações e implicações, que anteriormente haviam sido quase totalmente negligenciadas. Não se pode, contudo, supor que os motivos econômicos sejam os únicos que determinam o comportamento dos seres humanos em sociedade [...]. É completamente incompreensível como os fatores psicológicos podem ser desprezados, ali onde o que está em questão são as reações dos seres humanos vivos; pois não só essas reações concorreram para o estabelecimento das condições econômicas, mas até mesmo apenas sob o domínio dessas condições é que os homens conseguem pôr em execução seus impulsos instintuais originais. (FrEUD, 1933, p. 173-174)

Já com relação à teoria de Adorno, ficou evidenciado que os conceitos de consciência em ambos não são equivalentes. Adorno, ao discutir a consciência, toma-a no sentido de racionalidade, analisando no que de fato esta se converteu na sociedade administrada. Seus escritos concentram uma análise crítica da sociedade e do homem que nela vive.

Para Adorno, na sociedade atual, consciência implica necessariamente inconsciência; racionalidade, irracionalidade. Apesar de se utilizar da teoria freudiana, Adorno não toma de empréstimo a mesma concepção de Freud a respeito da consciência. Em sua análise, busca elementos da teoria psicanalítica que possibilitem a apreensão dos motivos que levam os sujeitos a aderirem à irracionalidade da sociedade administrada.

Nos escritos de Adorno, a análise do conceito de consciência parece aproximar-se mais da teoria marxiana. Apesar de o interesse de Adorno concentrar-se na compreensão dos fatores subjetivos que permeiam a sociedade capitalista e, mais especificamente, no desenvolvimento da irracionalidade, ele parte da obra de Marx e tenta buscar em Freud elementos que possibilitem preencher algumas lacunas que considera presentes na análise marxiana. Contudo, vale ressaltar que Adorno não concilia as duas teorias.

Já Freud, ainda que tome a consciência em sua relação com o desenvolvimento da civilização, o faz conferindo ênfase às questões pulsionais do indivíduo e não a uma análise diante da racionalidade ou irracionalidade existente. 


\section{NOTA}

1. É preciso distinguir a palavra pulsão da palavra instinto. Segundo Zimmerman (1999), "'a palavra pulsão (empregada por Freud com o termo original alemão trieb) alude a necessidades biológicas com representações psicológicas, que urgem em ser descarregadas, sendo que é necessário distingui-lo de instinto (tradução do termo instinkt, que também aparece na obra de Freud, embora poucas vezes), o qual designa mais explicitamente fixos padrões hereditários de comportamento animal, típicos de cada espécie" (p. 77).

\section{ABSTRACT}

Based on a study of the works of Freud, Marx and Adorno, this article discusses the concept of conscience. The elements of analysis will be identified in some of their texts as well as the journey of each author towards development and understanding of the concept. An analysis of the points of convergence and differentiation of all three theorists concludes the article.

Key words: conscience; labor; civilization; individual.

\section{REFERÊNCIAS}

ADORNO, T. W. Teoria de la seudocultura. In: Filosofia y supertición. Madrid: Alianza Editorial, 1972.

. Acerca de la relación entre sociologia e psicologia. In: JENSEN, H. Teoria crítica del sujeito. Buenos Aires: Siglo XXI, 1986. p. 36-83.

Educação e emancipação. Tradução de Wolfgang Leo Maar. Rio de Janeiro: Paz e Terra, 1995.

ADORNO, T. W.; HORKHEIMER, M. Temas básicos da sociologia. São Paulo: Cultrix/USP, 1973

Dialética do esclarecimento: fragmentos filosóficos. Rio de Janeiro: Jorge Zahar, 1985.

CROCHÍK, J. L. A formação do indivíduo e a dialética do esclarecimento. Nuances: Revista do Curso de Pedagogia, Unesp, v. 7, n. 7, 2001.

$\mathrm{O}$ desencanto sedutor: a ideologia da racionalidade tecnológica. InterAção: Revista da Faculdade de Educação. Goiânia: Editora da UFG, v. 28, n. 1, jan.-jun. 2003. p.15-35.

FREUD, S. Formulações sobre os dois princípios do funcionamento mental. In: Obras psicológicas. Rio de Janeiro: Imago, v. XII, 1996. 
As pulsões e suas vicissitudes. In: Obras psicológicas. Rio de Janeiro: Imago, v. XIV, 1996.

Além do princípio do prazer. In: Obras psicológicas. Rio de Janeiro: Imago, v. XVIII, 1996.

A psicologia de grupo e a análise do ego. In: Obras psicológicas. Rio de Janeiro: Imago, v. XVIII, 1996.

O mal-estar na civilização. In: Obras psicológicas. Rio de Janeiro: Imago, v. XXI, 1996.

Novas conferências introdutórias sobre psicanálise. In: Obras psicológicas. Rio de Janeiro: Imago v. XXII 1996. p. 63-84 e 155-188.

IANNI, O. (Org.) Marx. São Paulo: Editora Ática, 1995.

MARX, K. Manuscritos econômicos-filosóficos. Lisboa: Edições 70, 1964. 1988.

O capital: crítica da economia política, v. I. São Paulo: Nova Cultural,

Trabalho assalariado e capital. São Paulo: Global Editora, s.d.. p 11-49.

MARX, K; ENGELS, F. Manifesto do Partido Comunista. São Paulo: Cortez, 1998.

A ideologia alemã. São Paulo: Martins Fontes, 2002.

ZIMERMANN, D. E. Fundamentos psicanalíticos: teoria, técnica e clínica uma abordagem didática. Porto Alegre: Artmed, 1999. 
